UNDERGROUND MINING ENGINEERING 35 (2019) 73-79 $\quad$ UDK 62

\title{
THE IMPACT OF CALCULATION OF RESOURCES AND RESERVES ON MINING ACTIVITY IN SERBIA
}

\author{
Jelena Zakonović ${ }^{1}$, Katarina Urošević ${ }^{2}$ Radmila Gaćina ${ }^{2}$
}

Received: Octobar 5, 2019

Accepted: November 6, 2019

\begin{abstract}
The appearance of interest of the world's most important mining companies i for investment in Serbia imposes the problem of harmonization of domestic legislation with foreign ones. In this paper, specific categorization and classification of mineral raw materials, which do not match in domestic and foreign practice, are treated. The existence of such a conflict of criteria in use for categorization and classification can lead to misunderstanding and create certain complications in business. The following sections outline some of the disagreements that are present in comparing our regulations with the world ones.

Keywords: geological exploration; deposits; solid mineral raw materials; mineral projects; mineral resources and reserves;
\end{abstract}

\section{INTRODUCTION}

Changes in the economy system in our country, adapting to market mode of business, leave a trace in every spheres of economics. So it is in mining, or wider, in an industry whose work is based on the use of mineral raw materials.

The emergence of important world-wide companies, on our region is conditioned by the mineral potential of Serbia. We are witnessing the presence of companies from: USA, Canada, Russia, China, Germany, United Kingdom etc. Next to foreign, domestic private companies play an important role. The ones with more or less success, are operating in the market, where there is significant competition, which is the case today in our country. Here we should point out that beside private companies, there are public enterprises for the production of coal as well as generating electricity, which are state-owned (EPS, RB Kolubara, TE-KO Kostolac, JP for REU, Resavica etc.). Also, there are stock companies (production and processing of liquid and gaseous hydrocarbons) with majority share of foreign capital, but with state ownership over a certain percentage of shares (NIS A.D.).

\footnotetext{
${ }^{1}$ Metalfer, d.o.o. Bulevar Mihajla Pupina 115 A, 11000 Belgrade, Serbia

${ }^{2}$ University of Belgrade - Faculty of Mining and Geology

Emails:jelena.zakonovic@metalfer.net;katarina.urosevic@rgf.bg.ac.rs;radmila.gacina@rgf. rs;
} 
Changes are also reflected in the ways of funding research and exploitation of mineral raw materials. Also, the current question is charging a fee for the use of mineral raw materials.

It can be noted that the activity on research and exploitation as well as the use of mineral raw materials plays an important role in the economy of the Republic of Serbia. We dare to conclude that this role can be far more significant.

In tentative terms, new ways of business involve appropriate institutional solutions. More precisely, the appropriate institutions are a precondition for efficient and quality work in the mineral economy.

Guided by the idea that the role of the state, among other things, is to give a legal framework for a certain activity, as well as to control how the activity is done, new institutions were constituted or there has been an adjustment of existing institutions to the new requirements. Certainly, legal regulations suffered some changes.

And as usual, despite the effort to coordinate domestic legal regulation with the one that is present in countries with highly developed economy, there are some areas that are anachronous, and they must be in the focus of attention of the administration, expert and scientific public. This refers specifically to the classification and categorization of mineral resources and reserves. The fact is that the classification used in our country is not entirely in line with contemporary trends. As a result, certain problems in planning, designing, evaluating projects can be given at all in developing investment technical documentation. Problems may arise in the process of obtaining the necessary approvals, in particular, "Approvals for the Exploitation of Mineral Raw Materials" and "Approval for the exploitation field ".

\section{RESULTS OF GEOLOGICAL EXPLORATIONS}

The results of geological exploration of deposits of raw materials play a very important role in mining. In the documentation of mining projects as basic parameters are used, above mentioned results of geological research in combination with other technical and economic data. First of all, these data must have an adequate level of reliability, so that mining projects can be successfully implemented.

In our mining legislation, the Rulebook (Pravilnik, 53/79) of the classification and categorization of solid mineral raw materials and keeping records of them is in use. Since this Rulebook has been in use since 1979, it should be borne in mind that this categorization and terminology used is outdated and is not in accordance with world standards (Ilić, 2017). 
According to the current Rulebook (Pravilnik, 53/79), the reserves of solid mineral raw materials $\mathrm{A}, \mathrm{B}$ and $\mathrm{C}_{1}$ categories are calculated, $\mathrm{C}_{2}$ reserves are estimated, while the $\mathrm{D}_{1}$ i $\mathrm{D}_{2}$ categories are assumed (Ilić, 2017). According to the Rulebook (Pravilnik, 53/79), and depending on the possibility of exploitation, the reserves of solid mineral raw materials classified in A, B and $\mathrm{C}_{1}$ categories, are classified as balance reserves and offbalance reserves, while categories $\mathrm{C}_{2}, \mathrm{D}_{1}$ and $\mathrm{D}_{1}$ are considered as prospective and their classification is not included in the balance or off-balance reserves. In our mining practice based on the technical-economic evaluation, the distribution of reserves of solid mineral resources to the balance or off-balance reserves is carried out. Exploitation reserves are, in fact, the balance reserves, reduced for the losses in the actual exploitation, in accordance with the Rulebook (Pravilnik, 53/79).

According to the new proposed Rulebook (Ilić et al., 2012) which is based on the PERC Standard (PERC Standard, 2013), mineral reserves only correspond to the exploitation reserves of the current Rulebook (Pravilnik, 53/79), mineral resources correspond to reserves $\mathrm{A}, \mathrm{B}, \mathrm{C}_{1}$ and $\mathrm{C}_{2}$ categories, and the results of geological exploration correspond to reserves $D_{1}$ and $D_{1}$ categories as shown in the Table 1 .

Table 1 Comparative overview of the classification of solid mineral resources according to the current Rulebook (Pravilnik, 53/79) and mineral reserves, mineral resources and exploration results from the proposed new Rulebook (Ilić et al., 2012) based on the PERC

Standard (PERC Standard, 2013) (Table adopted from (Ilić, 2017.))

\begin{tabular}{|c|c|c|c|c|c|c|}
\hline \multirow{2}{*}{$\begin{array}{l}\text { Proposed } \\
\text { new } \\
\text { Rulebook }\end{array}$} & \multirow{2}{*}{$\begin{array}{l}\text { Research } \\
\text { results }\end{array}$} & \multicolumn{3}{|c|}{ Mineral resources } & \multicolumn{2}{|c|}{ Mineral reserves } \\
\hline & & Inferred & Indicated & Measured & Probable & Proved \\
\hline \multirow{3}{*}{$\begin{array}{c}\text { Current } \\
\text { Rulebook }\end{array}$} & \multicolumn{6}{|c|}{ Reserves of mineral raw materials } \\
\hline & Potencial & Potencial & \multicolumn{2}{|c|}{$\begin{array}{c}\text { Determined reserves } \\
\text { (off balance and } \\
\text { balance reserves, } \\
\text { geological -in situ) }\end{array}$} & \multicolumn{2}{|c|}{$\begin{array}{l}\text { Exploitation reserves } \\
\text { (balance reserves } \\
\text { reduced for the losses } \\
\text { for exploitation) }\end{array}$} \\
\hline & $\begin{array}{l}D_{1} \text { and } D_{2} \\
\text { categories }\end{array}$ & $\begin{array}{c}\mathrm{C}_{2} \\
\text { category }\end{array}$ & $\begin{array}{c}\mathrm{C}_{1} \\
\text { category }\end{array}$ & $\begin{array}{c}\text { B i A } \\
\text { categories }\end{array}$ & $\begin{array}{c}\mathrm{C}_{1} \\
\text { category }\end{array}$ & $\begin{array}{c}\text { B i A } \\
\text { categories }\end{array}$ \\
\hline
\end{tabular}

Our legislation (Pravilnik, 53/79), allows following errors in the calculation of the "reserves": for A category $\pm 15 \%$, B category $\pm 30 \%$ and for $\mathrm{C}_{1}$ category $\pm 50 \%$.

In modern world practice, the permissible errors in estimating mineral resources/ reserves are: for measured resources and the proven reserves $\pm 10-15 \%$, for the indicated resources and probable reserves $\pm 20-30 \%$, and for inferred resources $\pm 30-50 \%$.

By comparing our classification and categorization with PAN-EUROPEAN RESERVES \& RESOURCES REPORTING COMMITTEE (PERC Standard, 2013), 
Mineral reserves correspond only to exploitation reserves from the valid Rulebook (Pravilnik, 53/79), respectively mineral resources correspond to reserves A, B, $\mathrm{C}_{1}$ and $\mathrm{C}_{2}$ categories, and the results of geological research correspond to the reserves $\mathrm{D}_{1}$ and $\mathrm{D}_{2}$ categories.

A similar situation is when it comes to some other classifications and categorizations which are widely implemented, such as:

- The Australasian Code for Reporting of Exploration Results, Mineral Resources and Ore Reserves ('the JORC Code'),

- Canadian CIM classification (NI 43-101),

- The South African Code for the Reporting of Mineral Resources and Mineral Reserves (SAMREC).

To emphasize, it was mentioned that in our country the balance or economic exploitability of mineral resources is determined by a technical and economical evaluation in accordance with the Rulebook (Pravilnik, 53/79). Foreign practice is different (Ilić, 2017), balances are determined based on analysis of the so-called modification factors. At the end of the stage of previous and detailed explorations, the technical, economical and other relevant data, are extracted and considered by competent person or persons. The most significant data from that are applied as modification factors.

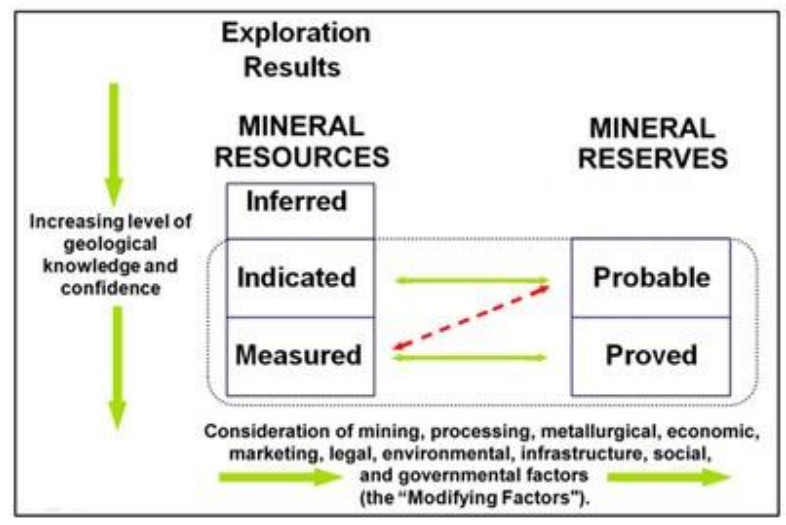

Figure 1 Reporting codes framework with three main categories - Exploration Results,

Mineral Resources, and Mineral Reserves (source: en.wikipedia.org/wiki/Mineral_resource_classification)

The disagreement between domestic and international regulations prevents the linear conversion of resources and reserves. All this can lead to significant misunderstandings 
in the interpretation of the exploration of mineral raw materials, especially when foreign companies perform the same. This disagreement has and consequences on mining activities, from the preparation of the investment technical documentation to the implementation of the same.

\section{EXAMPLES OF SOME LEGAL SOLUTIONS}

The practice of Western countries and their companies, which is dominant in the modern market way of business, involves several stages of the development of mining documents. Starting from Order of magnitude, over Preliminary feasibility to Detailed feasibility (De La Vergne, 2014).

Acceptable errors (De La Vergne, 2014) in these documents are:

- Order of magnitude (30) $40 \ldots .50 \%$;

- Preliminary feasibility $20 \ldots .30 \%$;

- Detailed feasibility $10 \ldots 15 \%$.

Based on these documents, classification and categorization of resources and reserves of mineral raw materials are performed.

Our practice and legal regulations recognize a larger number of mining investment and technical documents. According to article 84. Law on mining and geological explorations (Zakon, 101/2015) there are:

1) Pre-feasibility study;

2) Feasibility study of exploitation the deposits of mineral raw materials;

3) Long-term exploitation program;

4) Mining projects;

5) Annual Operational plan.

Mining projects are:

1) Main mining design;

2) Supplementary mining design;

3) Technical mining design;

4) Technical mining design for exploitation the mineral resources for obtaining the natural construction materials; 
5) Mining design involving explorations the solid mineral resources;

6) Simplified mining design.

All above mentioned documents have defined functions for certain phases of mining activities. However, there are situations for which the procedure and domain of application of individual documents have not been fully defined. For example, Law (Zakon, 101/2015) defines the role of a pre-feasibility study (Art. 86), but in practice there is no need to perform this activity. The aforementioned article says: "... Prefeasibility study on feasibility the exploitation of mineral resources has transferred the indicated and measured resources into probable and proven reserves of mineral resources...". On the other hand, a valid current regulation (Pravilnik, 53/79) not recognize the indicate and measured resources and the probable and proven reserves of mineral raw materials. The process of defining the balance sheet is based on the other principles described earlier. Therefore, the role of the pre-feasibility study is unclear.

A similar situation occurs in the case of a feasibility study of exploitation the deposits of mineral raw materials. The content and role of this study is defined in Art. 70 and 87 of the abovementioned Law. This study is a necessary document for obtaining approval for the exploitation field (Art. 70). The name implies that it is a document known as Detailed feasibility study, but if one looks carefully the valid one Rolebook about the content of a feasibility study of exploitation the deposits of mineral resources (Pravilnik, 108/2006) and compares with mentioned document, it will realise that it is not the same type of document.

Further, our mining practice permits the design and execution of mining operations on $\mathrm{C} 1$ category reserves, in accordance with the applicable Rulebook. All this implicates that it is very difficult to establish a link between reserves treated by foreign classifications and our current classification.

\section{CONCLUSION}

Because of different approaches in the categorization and classification of mineral resources, a very common case is the difference in the quantities and quality of mineral resources that are categorized as reserves in accordance with our and foreign practice. This can produce not only the misunderstanding but also significant consequences and all depending on the quantity and quality of mineral raw materials.

The aforementioned discrepancy between domestic and foreign regulations regarding categorization of reserves is a consequence of the application of different criteria for extraction of different classes of mineral resources. These criteria are not matched, therefore there is no possible conversion of resource classes and reserves towards foreign and domestic legal acts. 
Finally, it should be noted that the purpose of this paper is to draw attention to some of the issues that have arisen as a result of the incompleteness or inconsistency of domestic legislation with foreign practice. We have not given any specific solutions here, we leave it to the competent institutions, but we believe that in this way we constructively contribute to the improvement of working conditions in the mineral resource complex of the Republic of Serbia.

\section{REFERENCES}

Pravilnik o klasifikaciji i kategorizaciji rezervi čvrstih mineralnih sirovina i vođenju evidencije o njima (1979), Službeni list SFRJ, 53/79. [Online] Available from https://www.mre.gov.rs/doc/geologijarudarstvo/22_Pravilnik\%20o\%20klasifikaciji\%2 0i\%20kategorizaciji\%20rezervi\%20cvrstih\%20mineralnih\%20sirovina\%20i\%20vodje nju\%20evidencije\%20o\%20njima\%2053\%2079.pdf [Accessed 01/10/2019]

ILIĆ, M. (2017) Primena rezultata geoloških istraživanja ležišta čvrstih mineralnih sirovina u rudarstvu. Tehnika, 72, pp. 204-211.

ILIĆ, M., JELENKOVIĆ, R. and BELJIĆ, Č. (2012) Generalni osvrt na Pravilnik o izveštavanju o rezultatima geoloških istraživanja, resursima i rezervama čvrstih mineralnih sirovina i njihovoj klasifikaciji. In: Radovi X Međunarodne konferencije „OMC 2012“, Zlatibor, Oktobar 2012, Jugoslovenski komitet za površinsku eksploataciju, pp. 79-96.

PERC Standard (2013) Pan - European Standard for Reporting of Exploration Results, Mineral Resources and Reserves. [Online] Available from: http://www.vmine.net/PERC /documents/PERC REPORTING STANDARD 2013.pdf [Accessed 10/10/2019]

Zakon o rudarstvu i geološkim istraživanjima (2015), Službeni glasnik Republike Srbije, 101/2015. [Online] Available from: https://www.mre.gov.rs/doc/geologijarudarstvo Izakon\%20o\%20rudarstvu10.12.pdf [Accessed 11/10/2019]

DE LA VERGNE, J.N. (2014) Hard Rock Miner's Handbook. Edition 5. Edmonton, Alberta, Canada: Stantec Consulting. [Online] Available from: https://www.stantec. com/content/dam/stantec/files/PDFAssets/2014/Hard\%20Rock\%20Miner\%27s\%20Ha ndbook\%20Edition\%205_3.pdf [Accessed 11/10/2019]

Pravilnik o sadržini studije izvodljivosti eksploatacije ležišta mineralnih sirovina (2006), Službeni glasnik Republike Srbije, 108/2006. [Online] Available from: https://www.mre.gov.rs/doc/geologijarudarstvo/07 Pravilnik\%20o\%20sadrzini\%20stu dije\%20izvodljivosti\%20eksploatacije\%20lezista\%20mineralnih\%20sirovina.pdf [Accessed 11/10/2019] 